The Journal of Public Space

2017 | Vol. 2 n. I

\title{
VIEWPOINT
}

\section{Stand up for Public Space! \\ A networking event at the Habitat III conference and a global online campaign}

\section{Luisa Bravo}

City Space Architecture, Italy | luisa.bravo@cityspacearchitecture.org

Mirko Guaralda

Queensland University of Technology, Australia | m.guaralda.qut.edu.au

Hendrik Tieben

The Chinese University of Hong Kong, Hong Kong | hktieben@cuhk.edu.hk

\section{Luis Alfonso Saltos Espinoza}

LASE+CityUrb, Ecuador | alfonsosaltos@gmail.com

Manfredo Manfredini

University of Auckland, New Zealand | m.manfredini@auckland.ac.nz

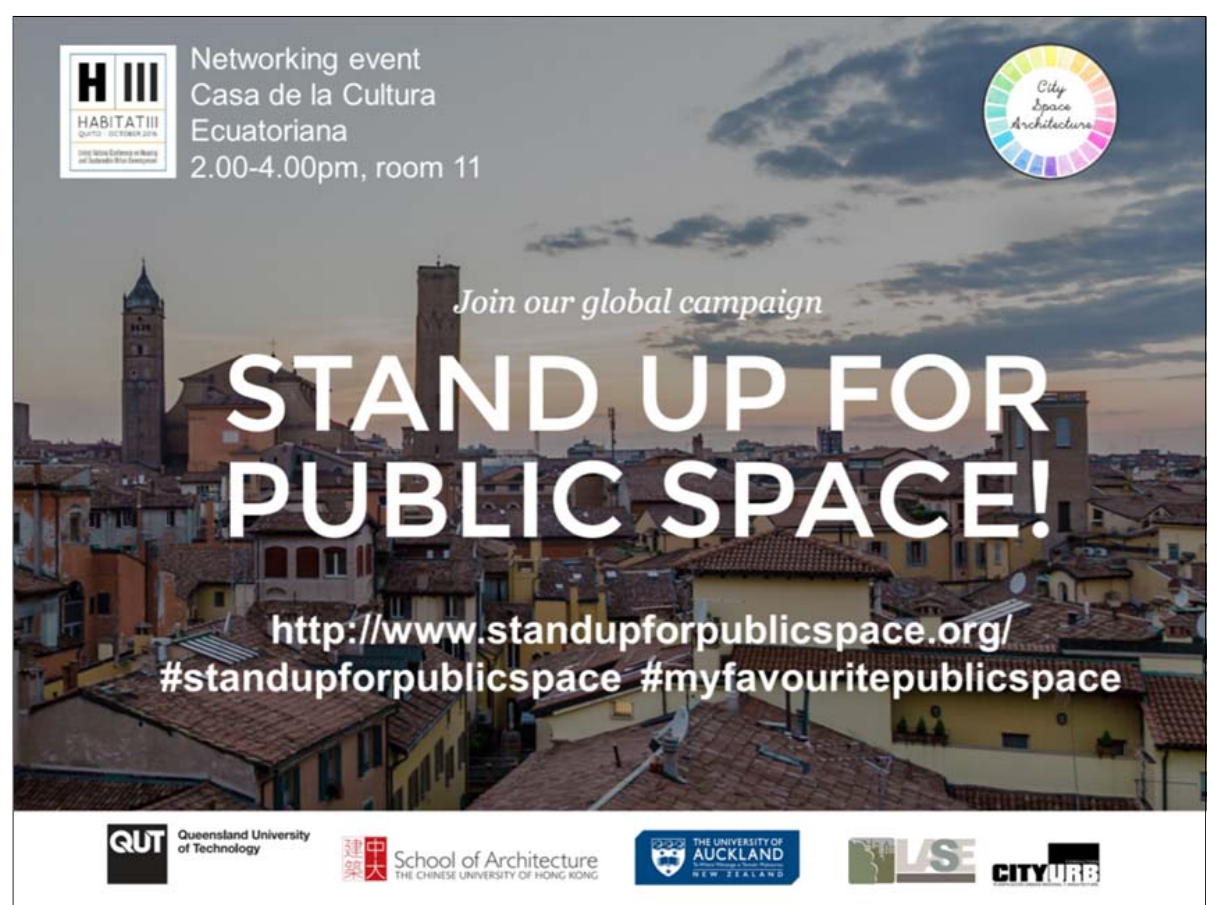

Fig. I. Cover picture from the website of the global online campaign: www.standupforpublicspace.org

At Habitat III, the United Nations conference on Housing and Sustainable Development, held in Quito, Ecuador (17-20 ${ }^{\text {th }}$ October, 2016), we launched the global online campaign 'Stand up for Public Space!' - www.standupforpublicspace.org - which is a research project promoted and powered by City Space Architecture, in collaboration with the Queensland 
University of Technology, The Chinese University of Hong Kong, LASE+CityUrb Ecuador and the University of Auckland (QUT Ethics Approval Number 1600000966). The purpose of this project is to foster a discussion on public space as a common good, through the collection of experiences, stories, habits and activities, documenting public space and its users from different geographical contexts. Participation will involve people taking a picture of their favourite public space and sharing it through their own Twitter or Instagram profiles. The project asks people to include also a short description of the picture, in order to know where the selected public space is located, what it means to them and why they would like to share it with a broader public. All entries are to be submitted using the following hashtags:

\section{\#standupforpublicspace and/or \#myfavouritepublicspace}

This project intends to provide a good insight of what a public space is for people in different countries and different continents. Data from the research will inform the development of a new taxonomy of public spaces and their uses, which might be useful to inform future planning documents and policies.
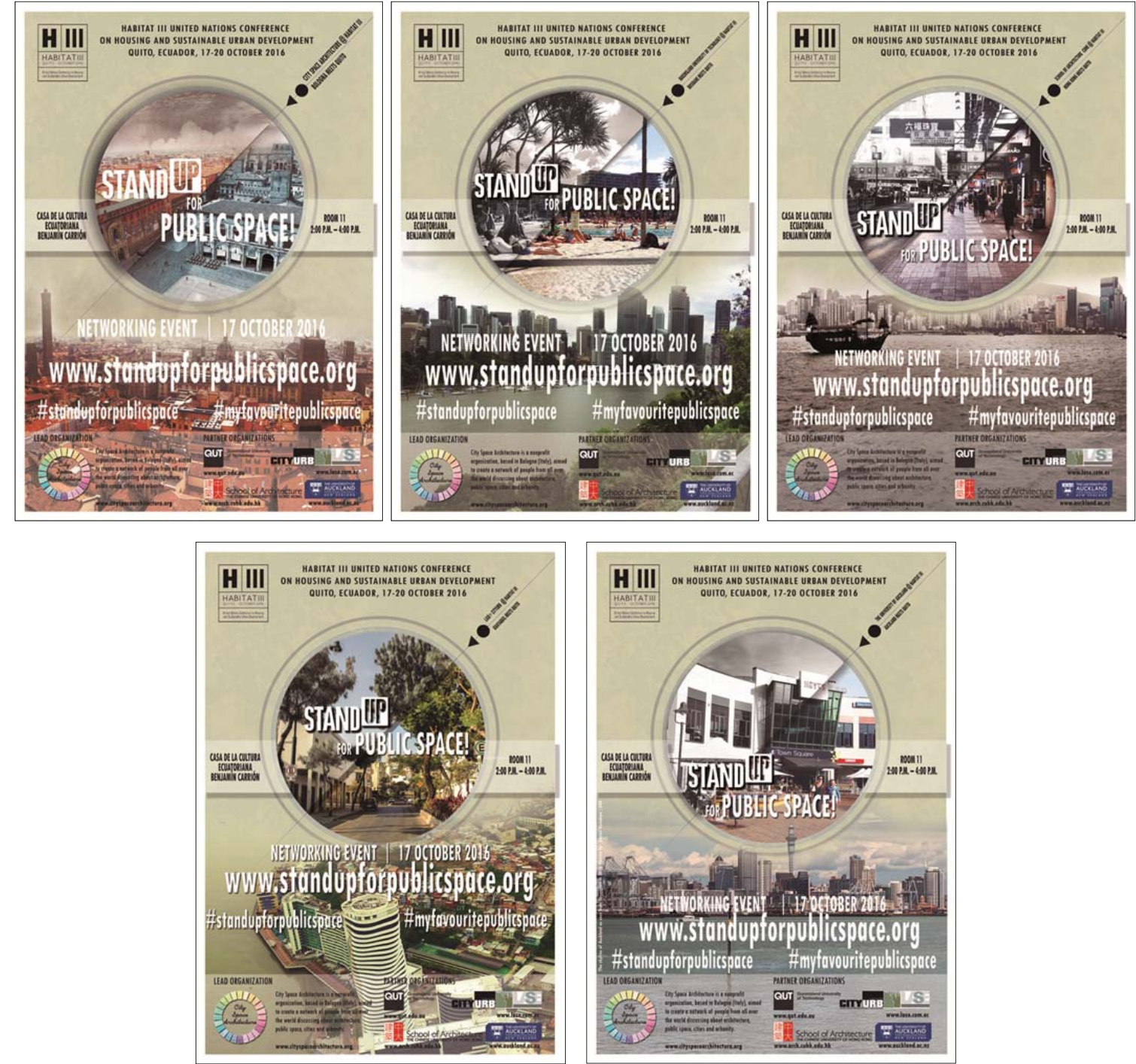

Fig. 2/6. Posters from the networking event at the Habitat III conference, with the five cities promoting the global campaign: from left to right, Bologna (Italy), Brisbane, (Australia), Hong Kong (China), Guayaquil (Ecuador) and Auckland (New Zealand). Graphic design by Arturo Del Razo Montiel. 
The networking event was selected among more than 1.000 proposals entered from all over the world and was included in the official programme of the conference. It was attended by more than 100 participants. We asked to the audience to contribute to the research project by providing some useful insights and reflections on public space: we divided the attendees in several groups (all English speaking but one Spanish speaking) and asked to each one of them to start a conversation, sharing concepts, definitions and problematics. We then asked to each group to summarize relevant outcomes from the discussion (in English with Spanish translation) and to share with them with us: public space was addressed referring to safety and security, appropriation and sharing, ownership and management, with a particular focus on privatization trends, community engagement, solidarity, participation and accessibility, design ability in response to rapid urbanization without lacking of identity and sensory experience, with some examples from specific contexts. Some groups discussed also about the public dimension in the digital domain and about shopping malls as new destinations for public life.

At the end of the discussion, we asked to the audience to reconsider their favourite public space in order to join the campaign. And we took a group picture!
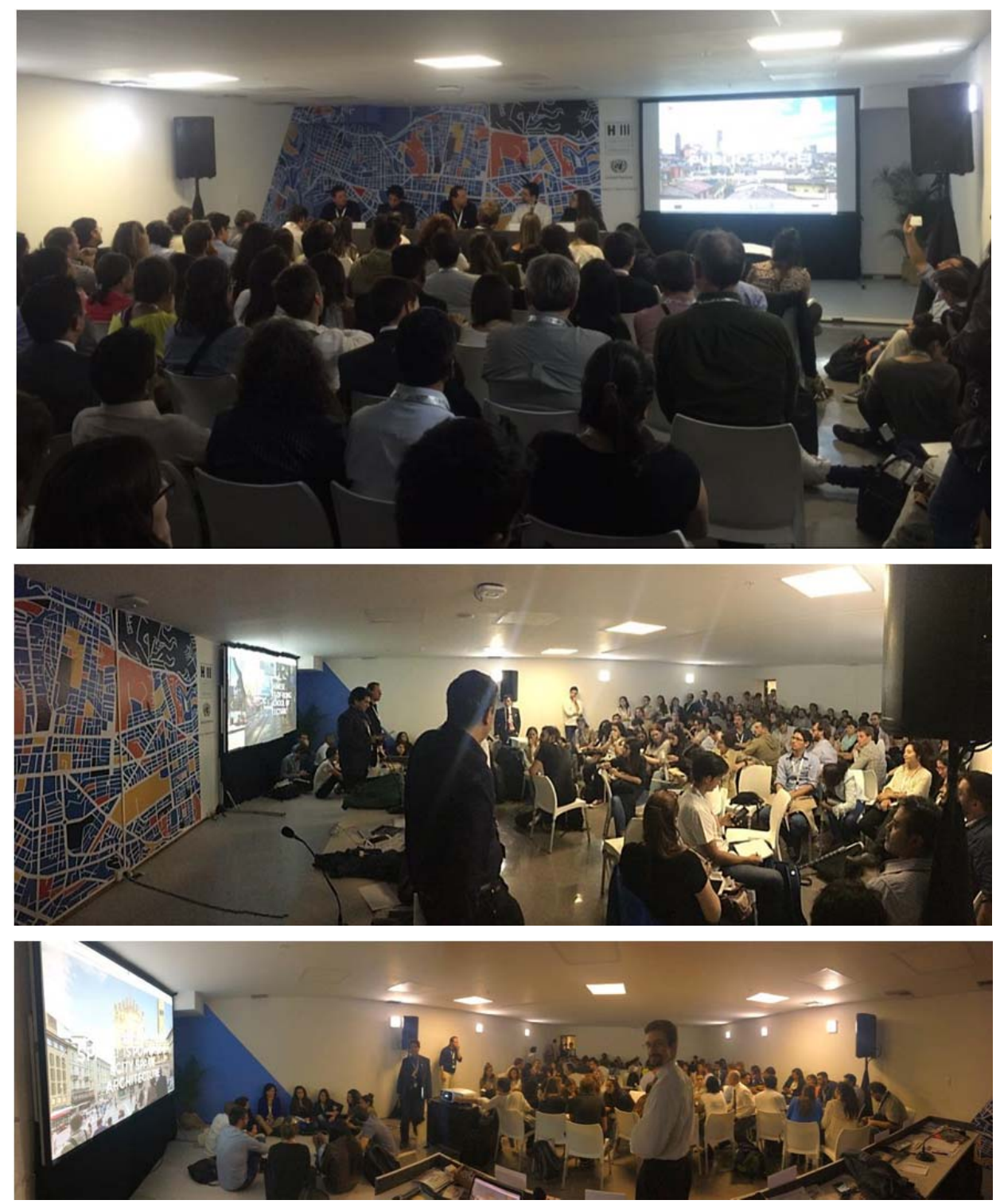

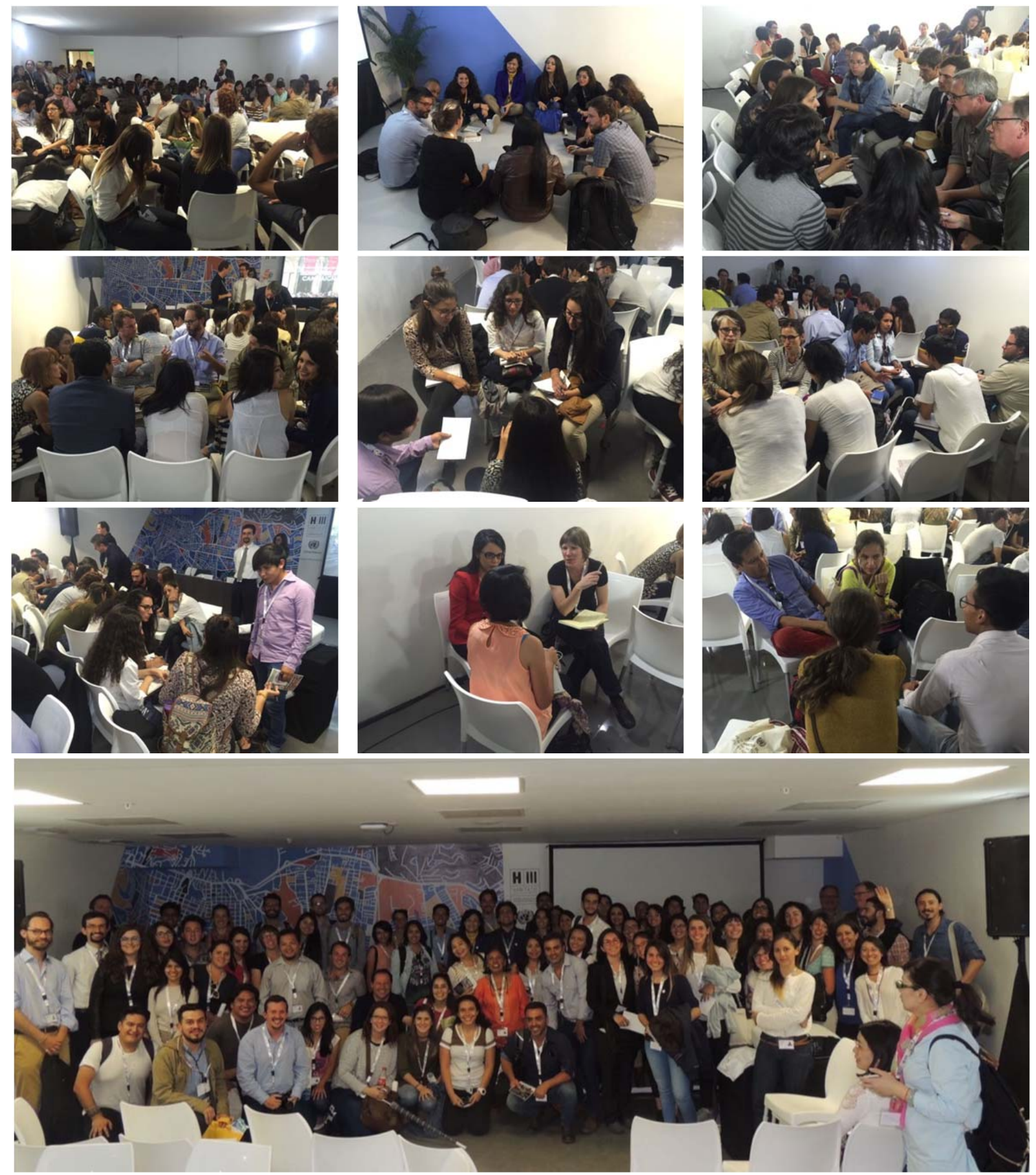

Fig. 7/I8. Some moments from the networking event at the Habitat III conference, on I7th October 20I6, Quito, Ecuador.

\section{To cite this article:}

Bravo, L., Guaralda, M., Tieben, H., Saltos Espinoza, L. A., Manfredini, M. (2017). Stand up for Public Space! A networking event at the Habitat III conference and a global online campaign, The Journal of Public Space, 2(I), I63-166, DOI: 10.5204/jps.v2il.6I

This article has been accepted for publication in The Journal of Public Space. Please see the Editorial Policies under the 'About' section of the journal website for further information.

(c) (i) This work is licensed under a Creative Commons Attribution - Non Commercial 4.0 International License. https://creativecommons.org/licenses/by-nc/4.0/

I66 | The Journal of Public Space, 2(I), 20I7| ISSN 2206-9658

(c) Queensland University of Technology 